\title{
Biodiesel Production from Spirulina Microalgae and its impact on Diesel Engine Characteristics-Review
}

\author{
Mariam Emad Murad ${ }^{a}$, Mohamed F. Al-Dawody ${ }^{a *}$ \\ ${ }^{a}$ Department of mechanical engineering, University of Al-Qadisiyah, Al-Qadisiyah, Iraq
}

\begin{tabular}{l} 
A R T I C L E I N F O \\
\hline Article history: \\
Received \\
Received in revised form \\
Accepted
\end{tabular}

Keywords:

Microalgae oil

AME production

Biodiesel properties

Engine performance

Emissions characteristics

\begin{abstract}
A B S T R A C T
This research aims to investigate the literature review on the extraction of algae oil, production of algae methyl ester (AME) biodiesel and the effect of microalgae biodiesel on the performance, combustion and exhaust emissions of diesel engine. The study dealt with researchers who published their reports between 2006 and 2020. Researches now concentrate on renewable energy, and biodiesel is one of the renewable energy sources. Biodiesel is a fuel similar to diesel and has many positive aspects such as quality, renewable energy, lower exhaust emissions, and greater lubricity. In addition to the use of microalgae in the production of fuels, they are used in reducing $\mathrm{CO}_{2}$ of the atmosphere which in turn results in better air quality to breathe and cleaner environment. Many researchers have paid attention to produce biodiesel derived from microalgae that represents one of the oldest living creatures on the globe. However, by comparing it with diesel, it has some drawbacks like lower heat content, higher density, viscosity, and NOx emissions. Optimization strategies are still recommended to fight the side effects of using biodiesel instead of original diesel fuel.
\end{abstract}

(C) 2020 University of Al-Qadisiyah. All rights reserved.

\section{Introduction}

For more than a century, the diesel engine engines have deep impact on the industrial economy, as they are used in a wide variety of applications that require mechanical motive power. Increasing tough emissions regulations coupled with fast depleting crude oil resources have caused a stimulation of interest in finding alternative fuels for petroleumbased fuels like diesel and gasoline [1]. Extracting oil from plant resources has attracted considerable attention. In many countries, vegetable oils are used after esterification as "biodiesel" [2]. Researchers have turned their interest towards fuel production from one of the oldest living creatures on the earth, microalgae. Besides their use of producing fuels, also for capturing the $\mathrm{CO}_{2}$ from the environment which gives better air quality to breathe. Algae are one of the most exciting future solutions for our energy crisis, especially that of transportation fuel. Algae need very low requirements to grow including carbon dioxide, sunlight, and water [3]. The objective of the present article is to conduct a comprehensive review starts from the oil extraction process, converting the extracted oil to biofuel and ends with the impact of using it as a fuel blended with diesel fuel on the performance, emissions, and combustion parameters of diesel engine.

\section{Extraction Algae oil}

The oil extraction refers to an operation that transfers one or more components of a solid or liquid phase to another liquid phase. Several methods are used to extract the oil from microalgae, such as mechanical extraction and chemical extraction. Solvent extraction process is more common than mechanical as it extracts almost all the oil and leaves in the

* Corresponding author. Tel.: +964 7814136944

E-mail address: mohamed.aldawody@qu.edu.iq (Mohamed Al-Dawody) 
raw material just (0.5- 0.7) percent of residual oil. The solvent extraction process can apply to any raw oil content materials [4]. The next lines summarize the recent literature papers that deal with the extraction process.

Baig et al. [5] explained the oil extraction process from microalgae spirogyra biomass by using $n$-hexane as a solvent. The authors studied and analyzed the effect of contact time, size of algal biomass, n-Hexane to oil proportion on the percent yield of oil extraction. It was noted that the maximum volume of oil was derived from the biomass of spirogyra using longer contact time, the smaller size of algal biomass, and a greater proportion of solvent to algal biomass. The study registered a 2.5 -fold rise in the algae-to-solvent ratios from 1:1 to $1: 3$ compared with the previous ratio.

Topare et al. [4] experimentally studied several methods of oil extraction from algae growing in the open pond system, such as hexane solvent extraction, mechanical pressing, etc. It was noted that the solvent method recovers nearly all the algae oil and leaves only $0.5 \%$ to $0.7 \%$ oil remaining in the material raw. Solvent extraction method was found to be a better method for the extraction of fats and oils, due to the higher percentage of oil recovered. The study pointed out that the expeller method could recover $75 \%$ of the oil from the microalgae.

Shimi et al. [6] described in detail the chemical extraction of algae oil from platensis-spirulina using several different solvents subjected to different conditions. The results showed that soxhlet extraction using methanol gives the highest rate of algae oil extraction (98.5\%) at 1 hour using biomass to solvent ratio of (1:110). Specifications of oil extracted, showed that viscosity is $58 \mathrm{mPa} . \mathrm{s}$, density is $0.89 \mathrm{~kg} / \mathrm{L}$ and the acid number is $37.4 \mathrm{mg} \mathrm{KOH} / \mathrm{g}$, because of these high values, the algae oil should be transformed to biodiesel by using the appreciated methodology. It was concluded that biodiesel derived from algae oil appears to be golden substitute fuel to reduce the dependence on petroleum fuels. The fatty acid in spirulina is palmitic acid $(48.35 \%)$ makes it a promising feedstock for the production of biodiesel.

A simple, friendly and energy-efficient method of extraction crude oil from microalgae utilizing dimethyl ether (DME) was presented by Kanda and Li. [7]. The authors tested this method on some kinds of natural microalgae (green-blue). As a result, green crude was effectively straight extracted from elevated moisture- microalgae (78.2-93.4\% water content), with an extraction rate changing from (9.9 to $40.1 \%$ dry weight) of the microalgae. The yield extracted by liquefied (DME) was contrasted with the Bligh-Dyer process widely used. The DME technique nearly attained efficient extraction similar to the Bligh-Dyer's method. It was also found that traditional methods are unable to remove green crude directly from elevated moisture microalgae.

A detailed description of the optimum conditions of the extraction oil method from microalgae- chlorella was presented by Abdullah et al. [8]. Soxhlet extraction method is used. It was found that the greatest extraction rate is $61.27 \%$ when using heptane as a solvent in the following conditions: $65{ }^{\circ} \mathrm{C}$ temperature of reaction, mixing rate of $600 \mathrm{rpm}$, and extraction time of 5 hours.

Yoo et al. [9] applied directly osmotic shock way to wet microalgae biomass with more $99 \%$ water content for the extraction of lipids, with both polar and non-polar organic solvents. The results indicated that osmotic shock increases lipid recovery nearly 2 times, and advised that it is a good technique to remove wet lipid from biomass of microalgae. Shah et al. [10] discussed the production of oil economics from the algae grown in open ponds by ultrasonic wave, soxhlet and expeller method. About $50 \%$ of algae oil was converted to biodiesel by using the transesterification process. The results highlighted that the soxhlet method was the most reliable method for oil extraction.

Shin et al. [11] investigated the performance, economic hurdles, special features of different methods to produce microalgae mass involving open pond, photo bioreactor, and immobilized culture procedures. The system of open ponds was considered the easiest, simplest, and least costly method. Despite this, their productivity is poor and easily infected with other microorganisms. The other widely used algal culture systems are the photo bioreactors. It can achieve double biomass efficiency as compared to open ponds along with greater control of pollution with complex designs of gas transfer, light dilution, and thermal insulation. Immobilized algae cultivation systems have huge potential to reduce the harvesting issue of open ponds and photo bioreactors and increase the productivity of biomass.

Wiyarone et al. [12] described the characteristics of microalgae oil extracted from Nannochloropsis sp. Two extraction processes were examined, soxhlet-assisted and ultrasonic-assisted. Both methods used ethanol as a solvent. The outcomes revealed that the concentration of ethanol influenced the quality of the algae oil. The better outcome achieved when the concentration of ethanol was $70 \%$. In the meantime, the amount of circulation also affects oil yield quality. The optimum time was 200 minutes. While the use of ultrasonic extraction significantly reduced the temperature and time. The GCMS test of algae oil components indicated that there was no noticeable difference between the two extraction methods is recorded.

Halim et al [13] used the supercritical carbon dioxide $\left(\mathrm{SCCO}_{2}\right)$ and hexane method for the extraction of the lipids from marine Chlorococcum. Various variables affect the efficiency of $\mathrm{SCCO}_{2}$ extraction, such as extraction time, type of algae used, temperature, and pressure. Compared to other lipid-rich microalgae organisms, the chlorococcus used in this study was calculated to have a relatively low lipid yield $(7.1 \%$ of dry biomass). The findings showed for $\mathrm{SCCO}_{2}$ extraction, decreasing temperature and increasing pressure resulted in increased lipid yields. The extraction of soxhlets using hexane is significantly less effective than the extraction of $\mathrm{SCCO}_{2}$, resulting in a comparable lipid yield (0.058 gram of lipid extracted per gram of dried microalgae). Table 1 listed the researcher's findings in a summarized way.

\section{Production of AME biodiesel}

With the ever-increasing demand for energy and impending depletion of fossil fuels, it has become necessary to find out sustainable source of energy. Promising alternatives closer to conventional diesel fuel include algae biofuels, particularly algae biodiesel have been used successfully powered diesel engines. One of the most popular methods used for the production of biodiesel is the transesterification process. The methanol along with sodium hydroxide as the base catalyst used to minimize the raw oil's free fatty acid content The specific parameters that influence the transesterification reaction are: the molar ratio of oil to methanol, the concentration of the catalyst, reaction temperature and time. The next coming studies related to the production of Algae methyl ester (AME) biodiesel via transesterification process.

Karmakar et al. [14] described the preparation of biodiesel from unused algae in two step procedure, acid esterification followed by transesterification. Taguchi's method was utilized to design the experiment. The best operating conditions for transesterification were selected at (methanol/oil) molar ratio of $6: 1,2.5 \mathrm{wt} \%$ catalyst $\mathrm{KOH}, 50{ }^{\circ} \mathrm{C}$ temperature, and $90 \mathrm{~min}$ of reaction time, getting $89.7 \%$ of a biodiesel 
production with $0.25 \%$ of content free fatty acid. It was found that diesel engines released less hydrocarbon, $\mathrm{CO}, \mathrm{CO}_{2}$, and higher $\mathrm{NOx}$ when using algal biodiesel instead of using petro-diesel. All properties of the produced biodiesel obtained were meeting ASTM standards.

Lardon et al. [15] provided an overview of the possible environmental effects of micro-algae biodiesel production. A virtual facility comparative life cycle assessment analysis was undertaken to assess the energy balance and possible environmental impacts of the entire process started from the processing of biomass up to the combustion of biodiesel as shown in figure (1). The results confirmed the ability of using microalgae as an energy source, but emphasize the imperative need to reduce energy consumption and fertilizer use. The regulation of nitrogen stress during cultivation and the optimization of wet extraction seemed to be useful options.

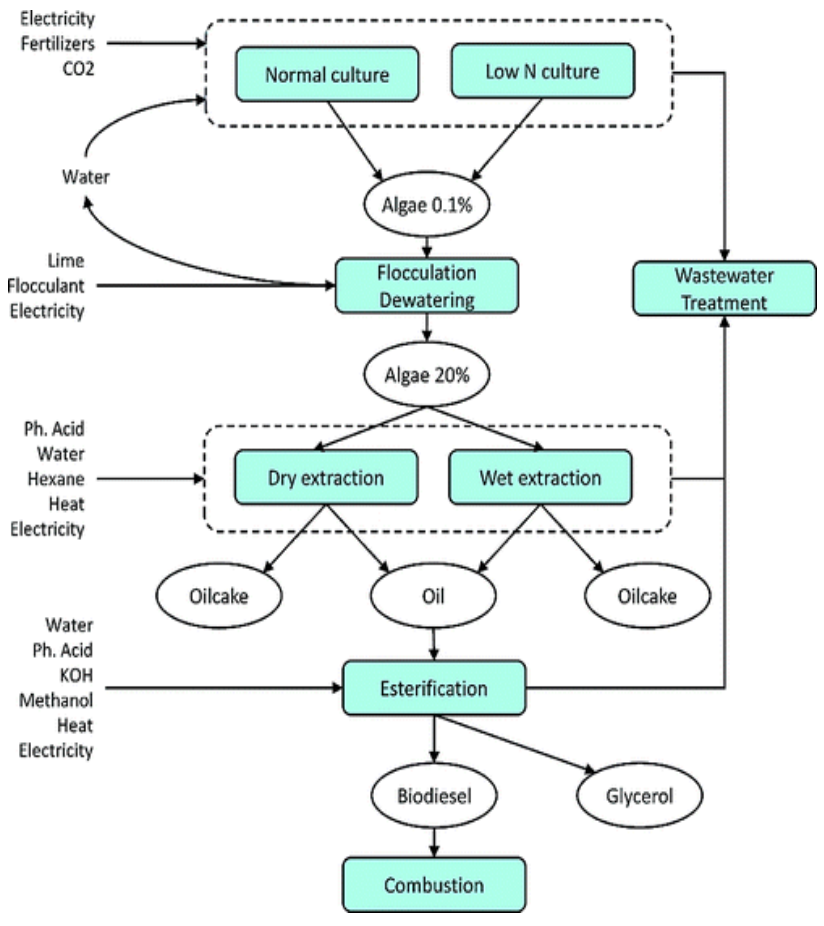

Figure (1) Schematic diagram for the production and testing of AME biodiesel

Sánchez et al. [16] examined the effect of added n-hexane on the transesterification of solid raw materials for the production of biodiesel. Algae oil extraction and reaction were performed concurrently in a batch reactor, incorporating $n$-hexane with the reactants. The findings revealed that $\mathrm{n}$-hexane has no major effect on the transesterification process. It has been noted that this method requires large amounts of methanol to perform the reaction. The reaction requirements for marine macro-algae transesterification were methanol/oil molar ratio $(300: 1), \quad 60^{\circ} \mathrm{C}$ temperature, and around 11 hours reaction time. This resulted in a yield of $17.1 \%$ methyl esters.

Miao et al. [17] developed a coordinate strategy to produce the biodiesel from heterotrophic microalgae oil. With the use of $n$-hexane, large amounts of microalgae oil were effectively extracted from heterotrophic cells. The best procedure of mixing was $100 \%$ catalyst amount, methanol to oil $56: 1$ molar ratio at a temperature of $30^{\circ} \mathrm{C}$ in around 4 hours response time, which reduced specific gravity from 0.912 to 0.8637 . The outcome indicated that the new technique, which incorporated transesterification and bioengineering, was a feasible and efficient approach for producing high-quality microalgae oil biodiesel.

Scott et al. [18] designed an overview of the potential algal biofuel pipeline and focused on previous researches aimed to improve the production of algal biomass and the fuel molecules contained within the algal cell. Figure (2) shows an approach for algal biodiesel development. Several factors need to be considered and optimized at each point, including inputs of energy and materials (e.g. nutrients and energy for mixing during growth).

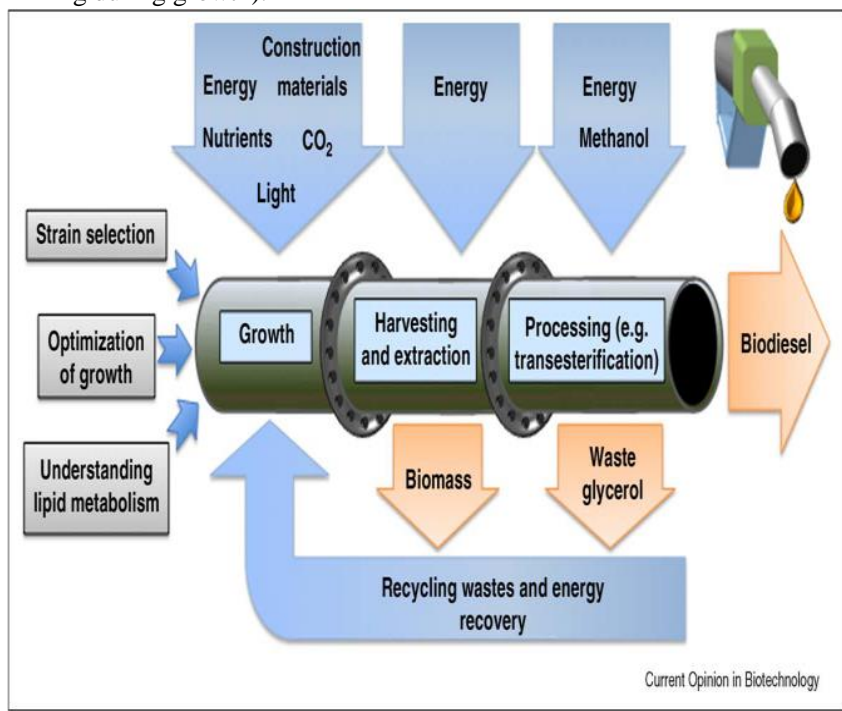

Figure (2) Algal biofuel pipeline

Hariram, et al. [19] derived algae oil methyl ester(AOME), from Spirulina microalgae grown in a photo bioreactor. A two-step solvent extraction method employing ether and hexane solvent was applied to obtain the algae oil. Cyclohexane was put into biomass to eliminate the residual algal oil. The percentage of algal oil was obtained in this method is $92 \%$. The transesterification method was applied to produce algal oil methyl ester by adding methanol and sodium hydroxide. The AOME was mixed with diesel at different blending ratios $(5 \%, 10 \%$, and $15 \%)$. It was noted that $\mathrm{CO}, \mathrm{HC}$, smoke, and particulates emissions decreased while a slight increase in the NOx emissions is reported.

Recently microalgae have achieved much interest because of their high oil contents and rapid growing rate. Tüccar and Aydın [20] focused on microalgae biodiesel as an alternative fuel in diesel engines. Biodiesel production of microalgae oil was mixed with diesel at $(5 \%, 10 \%, 20 \%$, and $50 \%$ ) blending ratio. The results displayed a reduction in brake power and torque values of the engine when using microalgae biodiesel while the emission values were reduced.

Kammakar et al. [21] studied the production of biodiesel from microalgae oil by transesterification reaction. Methanol is used along with $\mathrm{KOH}$ as the catalyst. They found that perfect conditions for obtaining minimum viscosity and free fatty acid content with maximum ester when using oil to methanol 1:6 molar ratio, $3 \mathrm{wt} \%$ of $\mathrm{KOH}, 1$ hour time, temperature of $60{ }^{\circ} \mathrm{C}$ and 2.5 hours of settling time. Most significant properties of ester biodiesel like fire and flash point $\left(158\right.$ and $\left.153{ }^{\circ} \mathrm{C}\right)$, viscosity $(3.12 \mathrm{~mm} 2 / \mathrm{s})$, carbon residue content $(0.03 \%)$, pour and cloud point $\left(-6\right.$ and $-1{ }^{\circ} \mathrm{C}$, respectively) were found within the range of ASTM/BIS standards.

Akubude et al. [22] worked on the production of biodiesel from microalgae via. transesterification process. The authors studied the 
production of microalgae, economic purposes of microalgae involving production of the fuel, food product extraction, $\mathrm{CO}_{2}$ capture for bio refinery resulting in the production of bio hydrogen, bio methane, and bioethanol. Issues included various groups of catalysts such as heterogeneous catalysts, homogenous catalysts, and enzymatic catalysts. The use of this technology for the production of biofuels can be commercialized for developing the biodiesel industry.

Gradual rise in carbon dioxide $\mathrm{CO}_{2}$ concentrations in the atmosphere because of the many anthropogenic activities resulting in major changes in the global carbon cycle. Therefore, microalgae appeared to be an effective medium for capturing extra $\mathrm{CO}_{2}$ existing in the atmosphere produced from various sources, like automobiles, power plants, and forest fires. Capturing $\mathrm{CO}_{2}$ through microalgae used as a significant source of carbon to produce lipids from biofuel to replace fossil fuel-derived transportation fuel without influencing crop and food supplies. Various parameters such as time, temperature, light intensity, $\mathrm{CO}_{2}$ concentration, $\mathrm{PH}$, and flow rate were discussed as a factor affecting on production of biodiesel in photo bioreactors. The results showed that using this method can reduce the proportion of $\mathrm{CO}_{2}$ in the atmosphere, and thus reduce global warming ( Mondal et al. [23]).

Ahmed et al. [24] collected the algae spirogyra spices from various regions of Pakistan and utilized it as a feedstock for production the biodiesel in two stages. During the first stage, the oil was extracted from algae using Di-ethyl Ether and n-hexane as solvents, while in the second step, extracted oil was converted to biodiesel through transesterification process. Almost $95 \%$ of biodiesel was obtained using catalyst (Sodium Hydroxide) amount of $0.5 \mathrm{wt} \%$, contact time of $25 \mathrm{~min}$ at $60{ }^{\circ} \mathrm{C}$ and $1: 8$ molar ratio of oil/methanol.

Fulke et al. [25] explained a feasible technology to convert microalgae lipids lived in a wastewater pond to biodiesel by using photosynthetic $\mathrm{CO}_{2}$. The highest $\mathrm{CO}_{2}$ fixation rate was observed in mixed algae samples, followed by chlorella. These findings indicated that biodiesel produced from microalgae lipids can indeed prove profitable, If grown under suitable nutrient and $\mathrm{CO}_{2}$ conditions, will lead to an ideal high biodiesel yielding cycle and effective sequestration of $\mathrm{CO}_{2}$.

Aljabarin et al. [26] studied the production of biodiesel from algae. The algae were taken from open ponds and then dried for 12 hours in the oven at $80^{\circ} \mathrm{C}$. Powder was gained by using a disc mill to grind the dried algae. Iron sulphate hydrate is added to the powder to obtain algae oil utilizing a distillation column. Methanol and potassium hydroxide as a catalyst were added to algae oil, the mixture then put in a separated funnel for around 10 hours until two layers of the mixture were obtained, the upper layer represents the biodiesel as shown in figure (3). The outcomes highlighted that biodiesel properties are similar to diesel, except that it decreases carbon dioxide $\mathrm{CO}_{2}$ emissions and sulfur dioxide $\mathrm{SO}_{2}$ emissions are not present.

Biodiesel production from algae oil through the transesterification process using methanol and $\mathrm{KOH}$ or $\mathrm{NaOH}$ as catalyst was presented by Tapore et al. [27]. Three moles from methanol reacted with one mole of triglyceride which creates a mixture of biodiesel and glycerin. It has been discovered that transesterification is a very successful method for reducing the viscosity of vegetable oils and making them suitable for use in such diesel engines without any modification. The finding showed biodiesel from algae oil decreases the greenhouse impact on the atmosphere, by reducing $\mathrm{CO}_{2}$ gas pollution, and improves the percentage of $\mathrm{O}_{2}$ in the exhaust gas compared to the ordinary diesel.

Chen et al. [28] developed a novel method for the production of biodiesel from wet microalgae. This method consisted of disrupting the microwave, removing partial water, extracting oil, and transesterification. The wet microalgae biomass with a moisture content of around $80 \%$ was employed as the raw material for the production of biodiesel. Methanol added to algae oil in different ratios such as 10:1, 8:1, 6:1, 4:1, and 2:1. In addition to $25,35,45,55$ and $65^{\circ} \mathrm{C}$ of reaction temperature and reaction time of $5,10,15,20,25$ and $30 \mathrm{~min}$. The results showed that the moisture content of wet microalgae decreased to approximately 50\% after disrupting the microwave, and removing partial water. The recovery of oil from pretreated microalgae reached $90 \%$ and transesterification conversion was greater than $90 \%$.

Hossain et al. [29] presented a study to know the correct transesterification, the amount of biodiesel production and the physical properties of biodiesel. The authors compared the volume of biodiesel production using the popular species Spirogyra and Oedogonium. The findings pointed, In Oedogonium, the production of algae oil and biodiesel was greater than in Spirogyra species as shown in figure (4). The main outcomes of all studies mentioned are listed briefly in Table 2 .

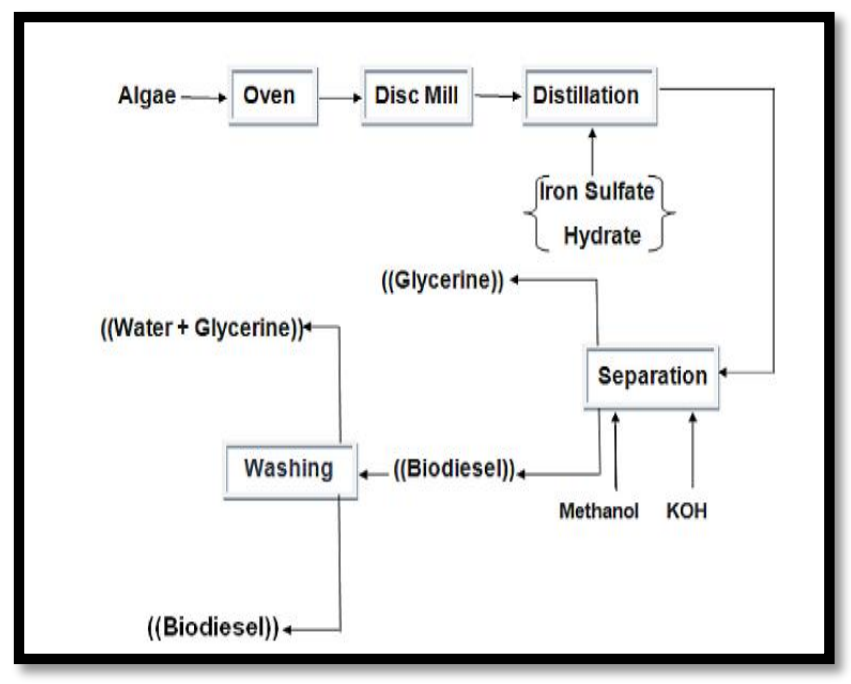

Figure (3) Flow diagram for the production of biodiesel from algae

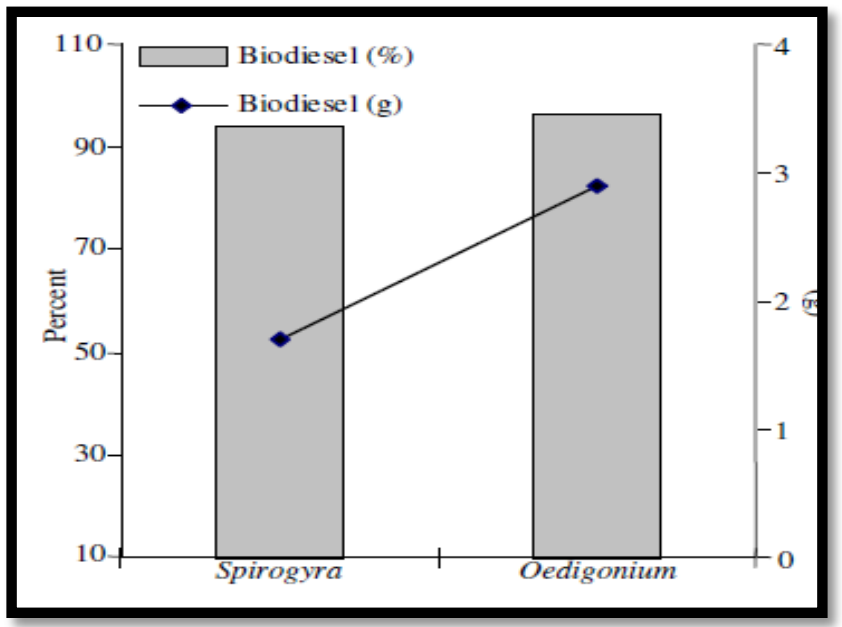

Figure (4) Biodiesel production in Spirogyra and Oedogonium sp. 
Table 1 Summary of algae oil extraction studies

\begin{tabular}{|c|c|c|c|}
\hline Reference & Micro(algae) & Extraction process & Conclusions \\
\hline Baig et al. [5] & Spirogyra sp. & $\begin{array}{l}\text { Solvent extraction process using } \mathrm{n} \text { - } \\
\text { hexane as solvent }\end{array}$ & $\begin{array}{l}\text { Maximum amount of oil obtained as the solvent to algae ratio } \\
\text { increased, longer contact time, smaller size of algal biomass }\end{array}$ \\
\hline Topare et al. [4] & Not declared & $\begin{array}{l}\text { hexane solvent extraction, expeller } \\
\text { method }\end{array}$ & $\begin{array}{l}\text { The solvent extraction process can be extended to any products } \\
\text { with a low oil content }\end{array}$ \\
\hline Shimi et al. [6] & Spirulina-platensis & $\begin{array}{l}\text { Solvent extraction process using } \\
\text { methanol as solvent (Soxhlet } \\
\text { Extraction System) }\end{array}$ & $\begin{array}{l}\text { The fatty acid in Spirulina is palmitic acid }(48.35 \%) \text { makes it a } \\
\text { promising feedstock for production the biodiesel }\end{array}$ \\
\hline Kanda and Li. [7] & microalgae (green-blue) & dimethyl ether (DME) & $\begin{array}{l}\text { This approach has the advantage of reusing the water drained as a } \\
\text { microalgae broth. }\end{array}$ \\
\hline Abdullah et al. [8] & Chlorella vulgaris & Soxhlet extraction method & $\begin{array}{l}\text { Too high temperatures in oil extraction can cause portion } \\
\text { decomposition of the microalgae cells and thus reduce oil yields }\end{array}$ \\
\hline Yoo et al. [9] & $\begin{array}{l}\text { Chlamydomonas } \\
\text { reinhardtii }\end{array}$ & osmotic shock treatment & osmotic shock increase lipid recovery nearly 2 times \\
\hline Shah et al. [10] & $\begin{array}{l}\text { Scenedesmus } \\
\text { dimorphus sp. }\end{array}$ & $\begin{array}{l}\text { ultrasonic wave, soxhlet and } \\
\text { expeller method }\end{array}$ & The best way of reduce work was the soxhlet system \\
\hline Shin et al. [11] & Not declared & Photo bioreactors (PBRs) & $\begin{array}{l}\text { Reduced } \mathrm{CO}_{2} \text { emissions, appealing for recycling exhaust gases } \\
\text { from power stations }\end{array}$ \\
\hline Wiyarone et al. [12] & Nannochloropsis sp. & Ultrasonic and Soxhlet extraction & Ethanol concentration has affected the quality of the algae oil \\
\hline Halim et al. [13] & marine Chlorococcum & $\begin{array}{l}\text { supercritical carbon dioxide } \\
\text { (SCCO2) }\end{array}$ & $\begin{array}{l}\text { decreasing temperature and increasing pressure resulted in } \\
\text { increased lipid yields }\end{array}$ \\
\hline
\end{tabular}

Table 2 Summary of algae biodiesel research works

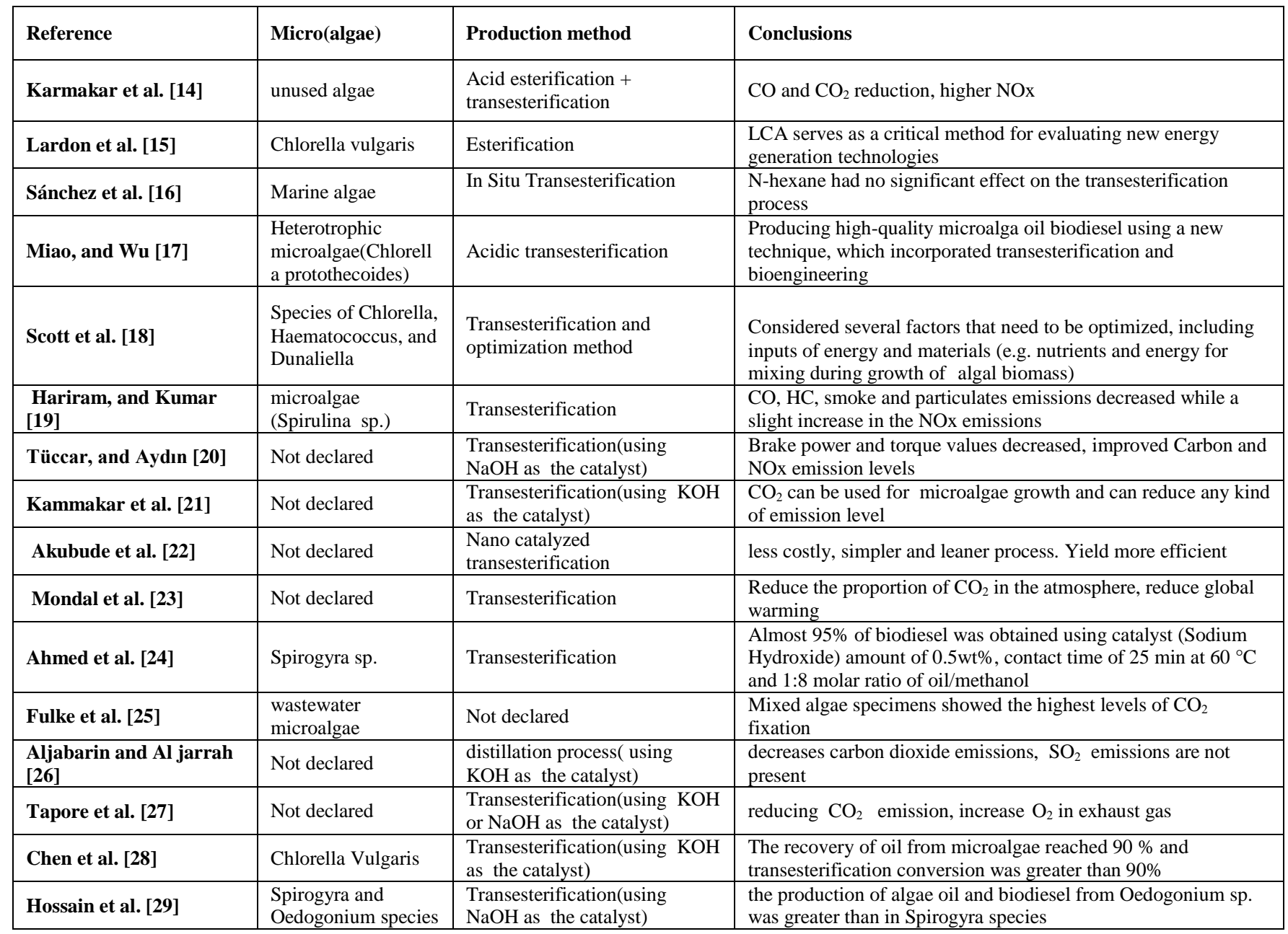




\section{Effect of microalgae biodiesel on the performance, combustion and exhaust emissions of diesel engine}

A great number of experiments were conducted by researchers from different parts of the world with biodiesel as a replacement for compression ignition diesel engine fuel.

Rajak et al. [30] investigated the characteristic of diesel engine numerically using the simulation Diesel-RK software. The engine is powered by pure algae biodiesel and diesel at different compression ratios from 16.5 to 18.5. Test engine experiments with an ideal compression ratio of 17.5 were conducted under maximum load conditions, and the results were compared with the numerical results. The products showed a $2.73 \%$ reduction in brake thermal efficiency, $6.66 \%$ reduction in torque, 1.6 reduction in exhaust gas temperature, $6.1 \%$ reduction in carbon dioxide, and $0.5 \%$ reduction in nitrogen oxide at full load condition under constant speed. However, SFC was increased by $6.4 \%$ at CR 17.5 as compared to pure diesel. Naresh et al. [31] studied the emissions and performance characteristics of a diesel engine (4-stroke, direct injection) using algae methyl ester oil with varying exhaust gas recirculation (EGR) control value of 5 to $20 \%$. Biodiesel and its mixtures displayed a significantly lower thermal brake efficiency relative to diesel fuel under various conditions of load. The energy consumption of fuels decreased as the amount of mixed fuels increases due to the reduced calorific values. NOx and HC are decreased as the amount of EGR increases. With higher rates of exhaust gas recirculation, the emissions and performance parameters are decreased. Therefore, $15 \%$ of EGR is optimal for fuels to improve their performance and emission characteristics. Rajak et al. [32] investigated the effect of spirulina microalgae biodiesel blending ratio on a naturally aspirated diesel engine at various loads. Combustion, emissions, and performance analyses reported a reduction in cylinder pressure, exhaust emissions, exhaust temperature, and brake thermal efficiency relative to diesel fuel. Regarding the emissions parameters, the spirulina microalgae biodiesel blends resulted in lower NOx emissions of $4.9 \%$, PM emissions of $20.7 \%$, and lower smoke of $5.4 \%$, but $\mathrm{CO}_{2}$ emissions for all loads is increased. Satputaly et al. [33] turned the microalgae oil gained from chlorella to biodiesel using the transesterification process. The produced biodiesel production was tested in Kirloskar diesel engine with capacity $5.2 \mathrm{~kW}$ to analyze the combustion, performance and emission. The tests revealed a $3.09 \%$ decrease in thermal brake efficiency. The findings showed a decrease in $\mathrm{CO}$, unburned hydrocarbons, nitrogen oxide and smoke opacity emissions when fueled with methyl ester microalgae oil relative to diesel.

Algae oil derived from microalgae using soxhlet having viscosity equal to 8 times that of diesel, was blended in three different amounts with sunflower as follow: $5 \mathrm{ml}$ of algae oil $+95 \mathrm{ml}$ of sunflower oil $(5: 95), 10 \mathrm{ml}$ of algae oil $+90 \mathrm{ml}$ of sunflower oil (10:90) and $15 \mathrm{ml}$ of algae oil $+85 \mathrm{ml}$ of sunflower oil (15:85) respectively, in order to reduce the viscosity. Furthermore, the above mentioned mixture was transformed into biodiesel through two-step transesterification method with methanol. Also, the three biodiesel forms produced were mixed in 10:90 $\mathrm{ml}$ with pure diesel (B10A\%, B10B\%, B10C\%) The study involved examination of chemical and physical properties. The biodiesel properties produced conform to ASTM measurements. The results showed that brake thermal efficiency is higher by $2.77 \%$ for the $\mathrm{B} 10 \mathrm{C} \%$ biodiesel than that of the conventional diesel. Likewise, the volumetric efficiency is increased by $1.52 \%$ for the B10C\% biodiesel when compared with Diesel (Sankar et al. [34]).
El-Baz et al. [35] described the biodiesel preparation from microalgae oil. Blends of $10 \%$ and $20 \%$ of biodiesel were prepared. The blends under study had physicochemical properties similar to diesel oil. Biodiesel blend B20 indicated declined in specific fuel consumption, exhaust gas temperature, and increased thermal efficiency relative to diesel fuel and B10. The emissions of B20 has been reduced as opposed to B10 and diesel. It could be inferred that microalgae could be used to supply high quality biodiesel which can feed traditional diesel engines efficiently.

Rajak, and Verma [36] investigated the characteristics of emulsion fuel with microalgae biodiesel (B20) and their consequences on exhaust emissions, combustion, and performance of a direct injection, diesel engine. The engine operated at three different engine speeds. The diesel engine powered by B0, B20, and B100 diesel at full load condition. The results showed, $0.55 \%, 6.2 \%, 1.63 \%, 2.6 \%$, and $1.2 \%$ reduction in indicated thermal efficiency, oxides of nitrogen, cylinder pressure, smoke emission, and brake thermal efficiency respectively. B20 showed an increase by $4.5 \%, 5.08 \%, 2.45 \%, 2.7 \%$, and $5.08 \%$ for peak heat release rate, specific fuel consumption, carbon dioxide emission, and ignition delay period respectively at $1500 \mathrm{rpm}$ with a full load. The numerical results are checked against the results of experiments carried out under the same operating conditions.

Murthy et al. [37] focused on biodiesel production from freshwater chlorella vulgaris algae. The authors used the various blends of algae biodiesel and diesel with variable loads to analyzed the emission, combustion, and performance characteristics of diesel engines. It was noted that B20 has higher brake specific fuel consumption due to the difference in the heating value compared to pure diesel. Reduction in NOx, CO and hydrocarbon emissions are observed.

Mahamudul et al. [38] explained that the usage of biodiesel and its blends marginally decreased engine power and raised fuel consumption but at the same time greatly lowered toxic emissions like hydrocarbons, particulate matter, carbon dioxides. The NOx emission is increased. $\mathrm{CO}_{2}$ emissions could be ignored as it is consumed by the crops themselves. It was fulfilled that biodiesel has the potential to be used in diesel engines as a substitute fuel for solving the energy and environmental crisis. Makarevičienè et al. [39] conducted an experimental study on the employment of biodiesel containing (30\% algae oil methyl esters (AME), and $70 \%$ fossil fuel) in VALMET 320 DMG diesel engine onboard ship. It was found that use B30 reduced smoke exhaust emissions to $10-75 \%$, and $5-25 \%$ reduction of hydrocarbons emissions (HC) with respect to diesel emissions. The engine thermal efficiency was $2.5-3 \%$ higher while operated on B30 compared to diesel fuel operation. Mathimani et al. [40] investigated the suitability of biodiesel derived from microalga chlorella vulgaris. Biodiesel-diesel blends were tested in a single cylinder diesel engine subjected to variable load operations $(0 \%, 50 \%, 75 \%, 100 \%)$ to analyze the performance and emission characteristics. Engine powered with $\mathrm{B} 50$ reduced the hydrocarbon and $\mathrm{CO}$ emissions by $102 \mathrm{ppm}$ and $0.1 \%$ respectively compared to baseline diesel. The results showed $6.1 \%$ reduction in $\mathrm{CO}_{2}$, and $376 \mathrm{ppm}$ reduction in nitrogen oxides NOx .

Reddy et al. [41] explained the possibility of using biodiesel derived from Schizochytrium microalgae oil as an alternative fuel for fossil diesel engines. Investigation was carried on diesel engine fuelled with microalgae biodiesel and its blends to evaluate the combustion, performance, and emission characteristics. The properties of biodiesel production were meeting the ASTM standards. The characteristics of the biofuel powered diesel engine compared with fossil fuel diesel engines were considered satisfactory. 
Haik et al. [42] conducted an experimental study using the raw algae oil and its methyl esters in a diesel engine. In this study, the effect of heat release, engine speed, injection timing, compression ratio, engine load, combustion noise, and maximum pressure were studied. The properties of the algae oil methyl ester were shown to be similar to diesel fuel and their use has been effective in the smooth running of the diesel engine. However, its use marginally decreased the output torque engine and increased the noise from the combustion. The engine output can be increased and the noise from combustion can be reduced by regulating parameters of the engine design like compression ratio and injection timing. Patel et al. [43] examined the suitability of biodiesel derived from Indian microalgae. Three different algal biodiesel blends namely $10 \%, 15$ $\%$, and $20 \%$ with fossil fuel, were tested on a diesel engine. Noticeable reduction in unburned hydrocarbon, brake specific fuel consumption, and carbon monoxide is reported. Moreover, the emissions NOx increased significantly. It can be inferred that diesel fuel can be effectively blended with biodiesel algae to minimize fossil dependence by promising performance characteristics without any engine modification.

The main concerns for the automobile industry are engine performance, emissions, and roughness. An experimental test was undertaken on a Ricardo E6 indirect injection engine with a single cylinder for three different biofuels compared to pure diesel." One of the three fuels used is algae methyl ester AME ". There were two primary sets of experiments; first experiment, the engine torque (load) ranged from 0.5 to $15 \mathrm{Nm}$, while the other parameters are injection timing, engine speed, and compression ratio. In second experiment, the injection timing ranged from $\left(20^{\circ}\right.$ to $\left.45^{\circ}\right) \mathrm{BTDC}$. The findings suggested that to accommodate the variety of biofuel characteristics, the fuel engine load and injection timing have to be adjusted. (Ospina et al. [44]). The results of all discussed studies are described shortly listed in Table 3.

Table 3 Engine performance

\begin{tabular}{|c|c|c|c|c|}
\hline Reference & Algae & Biodiesel tested & Engine & Conclusions \\
\hline Rajak et al. [30] & Spirulina sp. & B100 & $\begin{array}{l}\text { Single cylinder, four stroke, } 17.5 \\
\text { Compression ratio, } 3.7 \mathrm{~kW}\end{array}$ & $\begin{array}{l}\text { Reduction in brake thermal efficiency, , torque, exhaust gas } \\
\text { temperature, carbon dioxide nitrogen oxide when using } \\
\text { B100, increased in SFC }\end{array}$ \\
\hline Naresh et al. [31] & Not declared & B20, B40, B60 & $\begin{array}{l}\text { direct injection, , four stroke, water } \\
\text { cooled , } 17.5 \text { compression ratio, } 5.9 \\
\text { kW, Kirloskar Engine }\end{array}$ & $\begin{array}{l}\text { Lower thermal brake efficiency, NOx and HC decreases as } \\
\text { the amount of EGR increase for biodiesel }\end{array}$ \\
\hline Rajak et al. [32] & Spirulina sp. & $\begin{array}{l}\text { B0,B20, B40, } \\
\text { B100 }\end{array}$ & Kirloskar diesel & $\begin{array}{l}\text { Decrease in the ignition delay period as compared to } \\
\text { original diesel. decrease in EGT and BTE }\end{array}$ \\
\hline $\begin{array}{l}\text { Satputaly et al. } \\
{[33]}\end{array}$ & chlorella & $\begin{array}{l}\text { B0, B100, raw } \\
\text { algae oil }\end{array}$ & $\begin{array}{l}\text { Kirloskar diesel engine, single } \\
\text { cylinder, water cooled, capacity } 5.2 \\
\text { kw }\end{array}$ & $\begin{array}{l}\text { Reduction of CO, Unburned Hydrocarbons, NOx and } \\
\text { Smoke Opacity emissions }\end{array}$ \\
\hline Sankar et al. [34] & Spirulina sp. & $\begin{array}{l}\text { B10A, B10B, } \\
\text { B10C }\end{array}$ & $\begin{array}{l}\text { 5HP single cylinder, } 4 \text { stoke, water } \\
\text { cooled, diesel engine }\end{array}$ & $\begin{array}{l}\text { Higher brake thermal efficiency for B10C compared to } \\
\text { diesel, B10C gives the best result }\end{array}$ \\
\hline El-Baz et al. [35] & $\begin{array}{l}\text { Scenedesmus } \\
\text { obliquus }\end{array}$ & $\mathrm{B} 10, \mathrm{~B} 20$ & $\begin{array}{l}\text { Kirloskar, single cylinder four stroke, } \\
\text { water cooled, diesel engine }\end{array}$ & $\begin{array}{l}\text { Lower BSFC, EGT, higher brake thermal efficiency, lower } \\
\text { emissions for B20 }\end{array}$ \\
\hline $\begin{array}{l}\text { Rajak, and } \\
\text { Verma [36] }\end{array}$ & Spirulina sp. & B0, B20, B100 & $\begin{array}{l}\text { Single cylinder, four stroke, direct } \\
\text { injection, diesel engine }\end{array}$ & $\begin{array}{l}\text { Lower thermal efficiency, NOX, cylinder pressure, smoke } \\
\text { emission and particulate matter for B20 }\end{array}$ \\
\hline \begin{tabular}{|l|} 
Murthy, and \\
Kumar [37]
\end{tabular} & \begin{tabular}{|l|} 
Chlorella \\
vulgaris
\end{tabular} & $\mathrm{B} 10, \mathrm{~B} 20$ & $\begin{array}{l}\text { Kirloskar TV-I DI, four stroke, single } \\
\text { cylinder, capacity } 3.6 \mathrm{kw} \text {, water cooled }\end{array}$ & Reduction in NOx ,CO and hydrocarbo \\
\hline $\begin{array}{l}\text { Mahamudul et al. } \\
{[38]}\end{array}$ & Not declared & 1 & diesel engine & Increased in NOx and BSFC, reduction in brake power \\
\hline $\begin{array}{l}\text { Makarevičienė et } \\
\text { al. [39] }\end{array}$ & Chlorella sp. & B30 & $\begin{array}{l}\text { VALMET } 320 \text {.DMG diesel engine } \\
\text { onboard ship }\end{array}$ & $\begin{array}{l}\text { Reduced smoke exhaust emissions to } 10-75 \%, 5-25 \% \\
\text { reduction of hydrocarbons emissions }\end{array}$ \\
\hline $\begin{array}{l}\text { Mathimani et al. } \\
{[40]}\end{array}$ & $\begin{array}{l}\text { Chlorella } \\
\text { vulgaris }\end{array}$ & $\begin{array}{l}\text { B30, B40, B50, } \\
\text { B60, B100 }\end{array}$ & $\begin{array}{l}\text { Kirloskar, four stroke, single cylinder, } \\
\text { water cooled, }\end{array}$ & Decreases the hydrocarbon, $\mathrm{CO}, \mathrm{NOx}$ and $\mathrm{CO} 2$ emissions \\
\hline Reddy et al. [41] & $\begin{array}{l}\text { Schizochytriu } \\
\text { m sp. }\end{array}$ & $\begin{array}{l}\text { B20, B40 and } \\
\text { B60 }\end{array}$ & \begin{tabular}{|l} 
Kirloskar,AV1, single cylinder, \\
vertical, four stroke, capacity $3.7 \mathrm{kw}$
\end{tabular} & $\begin{array}{l}\text { Weak atomization and rising exhaust gas temperatures gave } \\
\text { lower thermal efficiency, lower HC, higher BSFC, NOx and } \\
\text { CO, decreased in ignition delay }\end{array}$ \\
\hline Y. Haik et al.[42] & \begin{tabular}{|l|} 
Ankistrodesmu \\
s braunii and \\
Nannochlorops \\
is. A. braunii
\end{tabular} & $\begin{array}{l}\text { B0, B50, raw } \\
\text { algae oil }\end{array}$ & $\begin{array}{l}\text { Ricardo E6 single cylinder, indirect } \\
\text { injection diesel engine }\end{array}$ & $\begin{array}{l}\text { Decreased the output torque engine and increased the noise } \\
\text { from the combustion, decrease in the compression ratio of } \\
\text { the engine resulted in diminishing the noise of combustion }\end{array}$ \\
\hline Patel et al. [43] & \begin{tabular}{|l} 
Chlorella \\
Vulgaris
\end{tabular} & B10, B15, B20 & $\begin{array}{l}\text { Kirloskar, single cylinder, vertical, } \\
\text { four stroke, water cooled }\end{array}$ & $\begin{array}{l}\text { Reduction in unburned hydrocarbon (UBHC), brake } \\
\text { specific fuel consumption (BSFC), carbon monoxide (CO). }\end{array}$ \\
\hline Ospina et al. [44] & Not declared & B0, B100 & $\begin{array}{l}\text { Ricardo E6, single cylinder, four } \\
\text { stroke, direct injection, diesel engine }\end{array}$ & Reduction in peak pressure, higher NOx emissions \\
\hline
\end{tabular}




\section{Conclusion}

This paper presents a comprehensive literature review of the most published papers in the field of extraction algae oil, algae biodiesel production, and its effect on performance, emission and combustion. A lot of points could be drawn:

- Although various sources of renewable energy are presently being used, the prospects of generating microalgae biofuels look promising due to their unique characteristics.

- The key of success in the microalgae biofuel production is the costefficient and successful extraction of lipids.

- Microalgae cells can produce and extract lipids. This lipid can be utilized in transformation to biofuel particularly biodiesel. This transformation reduces the emissions of petroleum, coal, nuclear power, hydro, and natural gas, which is a significant cause of greenhouse gas (GHG) emissions.

- Due to the higher oxygen content of the biodiesel compared with diesel, early start of combustion is observed.

- Sight reduction in the brake thermal efficiency is reported while the BSFC is increased.

- During the combustion process, biofuels may result in a decrease of toxic emissions such as $\mathrm{CO}_{2}, \mathrm{CO}$, unburnt hydrocarbon and soot.

- NOx is one of the important conditions for the diesel engine studies to be addressed. NOx forming in an engine is determined by the temperature of combustion and the rate of heat release. Consequently, the higher combustion temperature of the engines resulted in increased NOx emissions.

- Most literature papers in this context are based on experimental studies. A clear lack in the theoretical studies is detected, hence more theoretical and simulation works are required to bridge the gap.

\section{REFERENCES}

[1] M. F. Al-Dawody, s.K. Bhatti, Computational Combustion and Emission Analysis of Biodiesel in a Variable Compression Ratio Engine, Al-Qadisiyah Journal for Engineering Sciences, 12 (2019).

[2] M. Edam, M. F. Al-Dawody, Numerical Simulation for the Effect of Biodiesel Addition on the Combustion, Performance and Emissions Parameters of Single Cylinder Diesel Engine, Al-Qadisiyah Journal for Engineering Sciences, 12 (2019) 72-78.

[3] M. El-Sheekh, A. Abomohra, Biodiesel production from Microalgae, Industrial Microbiology: Microbes in Action, Garg, N., and Aeron, A.(Eds.). New York, Nova Science Publishers, (2016) 355-366.

[4] N.S. Topare, S.J. Raut, V. Renge, S.V. Khedkar, Y. Chavanand, S. Bhagat, Extraction of oil from algae by solvent extraction and oil expeller method, International Journal of Chemical Sciences, 9(4) (2011) 1746-1750.

[5] R.U. Baig, A. Malik, K. Ali, S. Arif, S. Hussain, M. Mehmood, K. Sami, A.N. Mengal, M.N. Khan, Extraction of oil from algae for biodiesel production, from Quetta, Pakistan, in: IOP Conference Series: Materials Science and Engineering, IOP Publishing, 2018, pp. 012022.

[6] H. El Shimi, N. Attia, A. Abdel Allah, S. El Sheltawy, G. El Diwani, Quality profile of Spirulina platensis Oilgae extraction for biodiesel production, Biotechnology, 5(3) (2015) 16-21.

[7] H. Kanda, P. Li, Simple extraction method of green crude from natural bluegreen microalgae by dimethyl ether: extraction efficiency on several species compared to the Bligh-Dyer's method, in: World Renewable Energy CongressSweden; 8-13 May; 2011; Linköping; Sweden, Linköping University Electronic Press, 2011, pp. 530-536.

[8] N. Abdullah, N.A. Amran, N.H.M. Yasin, Algae oil extraction from freshwater microalgae Chlorella vulgaris, Malaysian Journal of Analytical Sciences, 21(3) (2017) 735-744.

[9] G. Yoo, W.-K. Park, C.W. Kim, Y.-E. Choi, J.-W. Yang, Direct lipid extraction from wet Chlamydomonas reinhardtii biomass using osmotic shock,
Bioresource technology, 123 (2012) 717-722.

[10] G. Shah, A. Patidar, V. Urkude, A. Hurmale, S. Choudhary, Analysis and Characterization of Algal Oil by Using Different Chromatographic Techniques for the Higher Production of Biodiesel from, Scenedesmus Dimorphus, (2012) 2.

[11] Y. Shen, W. Yuan, Z. Pei, Q. Wu, E. Mao, Microalgae mass production methods, Transactions of the ASABE, 52(4) (2009) 1275-1287.

[12] B. Wiyarno, R. Yunus, M. Mel, Extraction of algae oil from Nannocloropsis sp.: a study of soxhlet and ultrasonic-assisted extractions, J Appl Sci, 11 (2011) 3607-3612.

[13] R. Halim, B. Gladman, M.K. Danquah, P.A. Webley, Oil extraction from microalgae for biodiesel production, Bioresource technology, 102(1) (2011) 178-185.

[14] R. Karmakar, K. Kundu, A. Rajor, Fuel properties and emission characteristics of biodiesel produced from unused algae grown in India, Petroleum Science, 15(2) (2018) 385-395.

[15] L. Lardon, A. Hélias, B. Sialve, J.-P. Steyer, O. Bernard, Life-cycle assessment of biodiesel production from microalgae, in, ACS Publications, 2009.

[16] A. Sánchez, R. Maceiras, A. Cancela, M. Rodríguez, Influence of n-hexane on in situ transesterification of marine macroalgae, Energies, 5(2) (2012) 243-257.

[17] X. Miao, Q. Wu, Biodiesel production from heterotrophic microalgal oil, Bioresource technology, 97(6) (2006) 841-846.

[18] S.A. Scott, M.P. Davey, J.S. Dennis, I. Horst, C.J. Howe, D.J. Lea-Smith, A.G Smith, Biodiesel from algae: challenges and prospects, Current opinion in biotechnology, 21(3) (2010) 277-286.

[19] V. Hariram, G.M. Kumar, Combustion analysis of Algal oil methyl ester in a direct injection compression ignition engine, Journal of Engineering Science and Technology, 8(1) (2013) 77-92.

[20] G. Tüccar, K. Aydın, Evaluation of methyl ester of microalgae oil as fuel in a diesel engine, Fuel, 112 (2013) 203-207.

[21] R. Karmakar, A. Rajor, K. Kundu, N. Kumar, Production of biodiesel from unused algal biomass in Punjab, India, Petroleum Science, 15(1) (2018) 164 175.

[22] V. Akubude, K. Nwaigwe, E. Dintwa, Production of biodiesel from microalgae via nanocatalyzed transesterification process: A review, Materials Science for Energy Technologies, 2(2) (2019) 216-225.

[23] M. Mondal, S. Goswami, A. Ghosh, G. Oinam, O. Tiwari, P. Das, K. Gayen, M. Mandal, G. Halder, Production of biodiesel from microalgae through biological carbon capture: a review, 3 Biotech, 7(2) (2017) 99.

[24] I. Ahmed, M. Ali, N. Ahmad, I. Ahmad, Production of biodiesel from algae, Journal of Pure and Applied Microbiology, 9(1) (2015) 79-85.

[25] A.B. Fulke, K.Y. Chambhare, L.N. Sangolkar, M.D. Giripunje, K. Krishnamurthi, A.A. Juwarkar, T. Chakrabarti, Potential of wastewater grown algae for biodiesel production and CO 2 sequestration, African Journal of Biotechnology, 12(20) (2013).

[26] N. Aljabarin, A. Al Jarrah, Production of biodiesel from local available algae in Jordan, Journal of Ecological Engineering, 18(6) (2017).

[27] N.S. Topare, V. Renge, S.V. Khedkar, Y. Chavan, S. Bhagat, Biodiesel from algae oil as an alternative fuel for diesel engine, Int J Chem Environ Pharm Res, 2 (2011) 116-120.

[28] C.-L. Chen, J.-S. Change, C.-C. Huang, K.-C. Ho, P.-X. Hsiao, M.-S. Wu, A novel biodiesel production method consisting of oil extraction and transesterification from wet microalgae, Energy Procedia, 61 (2014) 1294-1297.

[29] A.S. Hossain, A. Salleh, A.N. Boyce, P. Chowdhury, M. Naqiuddin, Biodiesel fuel production from algae as renewable energy, American journal of biochemistry and biotechnology, 4(3) (2008) 250-254.

[30] U. Rajak, P. Nashine, T.N. Verma, A. Pugazhendhi, Performance, combustion and emission analysis of microalgae Spirulina in a common rail direct injection diesel engine, Fuel, 255 (2019) 115855.

[31] V. Naresh, S. Prabhakar, K. Annamalai, P. Naveenchandran, Experimental investigation on characteristics of algae biodiesel in a diesel engine, International Journal of Engineering \& Technology, 7(1.9) (2018) 1-5.

[32] U. Rajak, P. Nashine, T.N. Verma, Effect of spirulina microalgae biodiesel enriched with diesel fuel on performance and emission characteristics of $\mathrm{CI}$ engine, Fuel, 268 (2020) 117305.

[33] S.S. Satputaley, D. Zodpe, N. Deshpande, Performance, combustion and emission study on CI engine using microalgae oil and microalgae oil methyl esters, Journal of the Energy Institute, 90(4) (2017) 513-521.

[34] S. Sankar, M. Kumaresan, G. Ragul, V. Jayakumar, C. Mathew, Performance of a Compression Ignition Engine with Blends of Biodiesel (from a mixture of Spirulina Microalgae Oil and Sunflower Oil) and Diesel, International Journal of Pure and Applied Mathematics, 119(16) (2018) 787-804. 
[35] F.K. El-Baza, M. Gadb, S.M. Abdoc, K. Abedd, I.A. Mattere, Performance and exhaust emissions of a diesel engine burning algal biodiesel blends, fuel, 10 (2016) 11.

[36] U. Rajak, T.N. Verma, Spirulina microalgae biodiesel-A novel renewable alternative energy source for compression ignition engine, Journal of cleaner production, 201 (2018) 343-357.

[37] G.P. Murthy, R. Kumar, Optimized production of biodiesel by fresh water algae oils derived from Chlorella wild stuff and performance characteristics of engine system by employing integration of chemical sciences and engineering technologies, (2019).

[38] H. Mahmudul, F. Hagos, R. Mamat, A.A. Adam, W. Ishak, R. Alenezi, Production, characterization and performance of biodiesel as an alternative fuel in diesel engines-A review, Renewable and Sustainable Energy Reviews, 72 (2017) 497-509.

[39] V. Makarevičienè, S. Lebedevas, P. Rapalis, M. Gumbyte, V. Skorupskaite, J. Žaglinskis, Performance and emission characteristics of diesel fuel containing microalgae oil methyl esters, Fuel, 120 (2014) 233-239.
[40] T. Mathimani, T.S. Kumar, M. Chandrasekar, L. Uma, D. Prabaharan, Assessment of fuel properties, engine performance and emission characteristics of outdoor grown marine Chlorella vulgaris BDUG 91771 biodiesel, Renewable energy, 105 (2017) 637-646.

[41] B. Rajendra Prasad Reddy, N. Rana Prathap Reddy, B. Manne, H. Srikanth, Performance, combustion and emission characteristics of a diesel engine fuelled with Schizochytrium micro-algae biodiesel and its blends, International Journal of Ambient Energy, (2020) 1-7.

[42] Y. Haik, M.Y. Selim, T. Abdulrehman, Combustion of algae oil methyl ester in an indirect injection diesel engine, Energy, 36(3) (2011) 1827-1835.

[43] J.S. Patel, N. Kumar, A. Deep, A. Sharma, D. Gupta, Evaluation of emission characteristics of blend of algae oil methyl ester with diesel in a medium capacity diesel engine, 0148-7191, SAE Technical Paper, 2014.

[44] G. Ospina, M.Y. Selim, S.A. Al Omari, M.I.H. Ali, A.M. Hussien, Engine roughness and exhaust emissions of a diesel engine fueled with three biofuels, Renewable Energy, 134 (2019) 1465-1472. 